\title{
ANALISIS IMPLEMENTASI E-BUDGETING DENGAN MENGGUNAKAN MODEL CIPP PADA PEMERINTAH PROVINSI DKI JAKARTA
}

\author{
Rama Andika Thio Rahman, Gugus Irianto, Rosidi \\ Fakultas Ekonomi dan Bisnis, Universitas Brawijaya Malang \\ Email: ramaandikathio@gmail.com
}

\begin{abstract}
This study aimed to analyze the effectiveness of e-Budgeting implementation in the Provincial Government of DKI Jakarta by using CIPP (Context, Input, Process, and Product) model from Stufflebeam (2003). The type of this research was a qualitative research with case-study approach. The data were collected using interviews and documentation studies. The results of this study reveal that the implementation of e-Budgeting in DKI Jakarta Provincial Government is feasible to proceed as it is proven to be effective in regards to the four components of CIPP Model. Observing the first component, context, e-Budgeting is successful in achieving the initial goal of budget transparency and accountability. Furthermore, in terms of input, the use of facilities, infrastructure and human resources was adequate. Viewed from the process, e-Budgeting simplified and minimalized errors in designing the work plan and budget (RKA). From the output (product), it improved the quality of regional budget (APBD) in terms of conformity with the Regional Medium-Term Development Plan (RPJMD) document and the control management of budget which plays an active role.
\end{abstract}

Keywords: e-Budgeting, CIPP, effectiveness, budgeting

\begin{abstract}
Abstrak
Penelitian ini bertujuan untuk menganalisis efektivitas dari implementasi e-Budgeting pada Pemerintah Provinsi DKI Jakarta dengan menggunakan model CIPP (Context, Input, Process, Product) dari Stufflebeam (2003). Jenis penelitian ini adalah penelitian kualitatif dengan pendekatan studi kasus. Teknik pengumpulan data berasal dari wawancara dan studi dokumentasi. Hasil penelitian ini mengungkapkan implementasi e-Budgeting pada Pemerintah Provinsi DKI Jakarta layak untuk dilanjutkan karena terbukti berjalan secara efektif bila ditinjau dari empat komponen Model CIPP. Pada komponen pertama, konteks (context), implementasi e-Budgeting berhasil mencapai tujuan awal, yaitu transparansi dan akuntabilitas anggaran. Selanjutnya ditinjau dari masukan (input), penggunaan sarana dan prasarana serta sumber daya manusia sudah memadai. Ditinjau dari proses (process), e-Budgeting mempermudah dan meminimalisasi kesalahan dalam proses penyusunan RKA. Serta, ditinjau dari output (product), e-Budgeting meningkatkan kualitas APBD dari sisi kesesuaian dengan dokumen perencanaan RPJMD, serta manajemen kendali anggaran yang berperan aktif.
\end{abstract}

Kata kunci: e-Budgeting, CIPP, efektivitas, anggaran

\section{Pendahuluan}

Lahirnya undang-undang No.14 tahun 2008 tentang keterbukaan dalam menyampaikan informasi publik secara substansial bertujuan untuk memberikan suatu jaminan konstitusional agar praktik demokrasi dan good governance bermakna bagi proses pengambilan kebijakan terkait kepentingan public [1]. Guna mewujudkan good governance, terutama dari segi akuntabilitas dan transparansi informasi publik, dibutuhkan langkah kebijakan yang terarah dalam perubahan sistem kelembagaan dan ketatalakasanaan melalui pemanfaatan ICT (Information and Communication Technologies) [2]. Selanjutnya, melalui Instruksi Presiden Republik Indonesia Nomor 3 Tahun 2003 dikeluarkan Kebijakan dan Strategi Nasional Pembangunan e-Government, yang menyatakan bahwa setiap Gubernur dan Bupati/Walikota diamanatkan untuk mengambil langkah-langkah yang diperlukan sesuai dengan tugas, fungsi, dan kewenangannya masing-masing demi terlaksananya pengembangan e-Government secara nasional [3]. 
E-Government telah berkembang pesat selama 15 tahun terakhir, United Nations Development Programme (UNDP) melakukan pengukuran terhadap E-Government Development Index (EGDI) atau yang disebut dengan indeks pembangunan e-Government yang memiliki kisaran nilai antara 0,25 sampai dengan 1,00. Posisi EGDI di Indonesia berada pada 0,25 - 0,50 (middle-EGDI). Rentang nilai ini terpaut jauh dengan nilai EGDI dari negaranegara Asia lainnya, seperti Singapura, Jepang, dan Israel yang memiliki nilai EGDI berkisar antara $0,75-1,00$ (high-EDGI) [4]. Berdasarkan hasil survey tersebut, dapat dikatakan bahwa pembangunan sistem $e$ Government di Indonesia masih cukup minim. Penggunaan sistem informasi yang tidak maksimal dalam proses pengelolaan pemerintahan akan menyebabkan tidak adanya efektivitas dalam memberikan pelayan terbaik kepada publik. Selain itu, kemungkinan untuk terjadinya kesalahan dalam mengelola sumber daya yang dimiliki oleh pemerintah khususnya proses pengelolaan keuangan akan semakin meningkat.

E-Budgeting merupakan salah satu perwujudan implementasi e-Government dalam mengelola keuangan pemerintah. Sistem ini dikembangkan untuk mempercepat proses perencanaan dan anggaran pemerintah. Selain itu, e-Budegting merupakan salah satu cara untuk menghadapi permasalahan internal organisasi pemerintah dalam menyusun anggaran. Penggunaan e-Budgeting sangat penting dalam rangka mewujudkan transparansi dan akuntabilitas dana anggaran untuk memberantas penyimpangan anggaran di daerah. Di Indonesia yang telah menerapkan sistem e-Budgeting di antaranya adalah Kota Surabaya dan Provinsi DKI Jakarta. Fenomena yang berkaitan dengan dana anggaran daerah pada Pemerintah Provinsi Jakarta di antaranya adalah kasus pengadaan truk sampah di Dinas Kebersihan. Pada tahun 2014, pengadaan truk kebersihan tidak dilakukan secara lelang, melainkan dengan pembelian secara $e$-Catalog. Namun, ketika akan melakukan pembayaran kepada pemegang kendaraan, truk yang dibeli tidak bisa dibayarkan karena kekurangan anggaran di Dinas Kebersihan sebanyak Rp11 miliar [5]. Salah satu kegagalan dalam mengimplementasikan suatu sistem ini dikarenakan adanya faktor manusia, yaitu penolakan atas sistem tersebut. Karenanya, penting untuk memahami mengapa seseorang menerima atau menolak sistem informasi berbasis tekonologi [6].
Berdasarkan fenomena dan kendala yang dihadapi dalam implementasi sistem $e$ Budgeting maka perlu dilakukan suatu evaluasi. E-Budgeting merupakan sistem yang telah dilaksanakan, sehingga penggunaannya perlu dinilai atau dievaluasi untuk melihat sejauh mana keberhasilannya dalam mencapai tujuan dan sasaran awal yang ditetapkan [7]. Evaluasi sistem informasi dapat dipandang dari dua sisi yaitu efisiensi dan efektivitas. Efisiensi menekankan pada kualitas ketersediaan sistem, misalnya kehandalan sistem, jumlah waktu akses, dan jumlah waktu downtime. Sedangkan, efektivitas mengkaji sistem informasi dari sisi kualitas yang dibandingkan dengan ekspektasi dan realitas sistem tersebut [7].

Pengukuran efektivitas sebuah sistem merupakan sesuatu yang sangat penting. Pemerintah daerah menghabiskan banyak biaya untuk membuat suatu sistem dan menerapkannya. Oleh karena itu, pemerintah daerah menaruh perhatian yang besar terhadap performa dari sistem yang dibuat. Beberapa hal menjadi alasan yang mendasari perlunya pelaksanaan pengukuran efektivitas sebuah sistem, di antaranya untuk menghindari kesalahan yang membawa konsekuensi kerugian finansial yang besar, contohnya adalah sistem tersebut tidak berhasil mengurangi penyelewangan dana anggaran. Dengan kata lain, perlu adanya evaluasi dalam mengukur efektivitas program $e$-Budgeting.

Teknik evaluasi yang digunakan dalam penelitian ini adalah model CIPP (Context, Input, Process, Product) dari Stufflebeams [8]. Model CIPP memiliki orientasi untuk memberikan layanan kepada berbagai model kebijakan dan program layanan masyarakat. Model evaluasi ini memiliki tujuan untuk menghubungkan informasi, konteks, input, dan proses dengan produk, serta menunjukkan ketersediaan lingkungan dalam rangka mencapai tujuan dan sasaran dari program yang dijalankan [9]

Evaluasi model CIPP tidak hanya bermaksud mengevaluasi aspek tertentu saja, namun dapat digunakan secara komprehensif untuk melihat berbagai hal terkait dengan suatu program dengan tujuan untuk memperbaiki program, termasuk program pembangunan. Hingga saat ini, belum banyak literatur yang mencoba menerapkan pendekatan evaluasi model CIPP, pendekatan ini dianggap cukup representatif dalam menggali implementasi suatu program. Dalam penelitian yang dilakukan oleh Hasan et al. [10], model CIPP ini digunakan karena model evaluasi ini dapat dilakukan secara terstruktur dan signifikan. 
Selain itu, karena model evaluasi ini dapat diukur efektifitasnya untuk mendapatkan hasil yang formatif, sumatif, dan juga memiliki kemampuan dalam memecahkan masalah yang terjadi. Atas dasar kondisi tersebut, disusunlah sebuah penelitian yang berfokus pada kerangka kerja dari model CIPP dengan tujuan agar dapat diperoleh suatu kerangka bantu dalam mengevaluasi implementasi sistem $e$-Budgeting. Kerangka bantu yang dihasilkan kemudian dicoba diterapkan untuk mengevaluasi program e-Budgeting pada Pemerintah Provinsi DKI Jakarta. Berdasarkan latar belakang di atas, tujuan penelitian ini adalah untuk menganalisis efektivitas implementasi program e-Budgeting pada Pemerintah Provinsi DKI Jakarta dengan menggunakan alat analisis model CIPP.

\section{Tinjauan Pustaka}

\section{Anggaran Sektor Publik}

Anggaran sektor publik memegang peran penting dalam proses pembangunan daerah. hal ini dikarenakan sektor publik merupakan proses untuk mengalokasikan sejumlah ssumber daya untuk mencapai tujuan dan sasaran yang sesuai dengan visi dan misi yang telah ditetapkan atau sesuai dengan RPJP atau RPJM daerah. Oleh karena itu, penting untuk mengetahui anggaran dan fungsi anggaran. Anggaran didefinisikan secara umum oleh Mardiasmo [11] yang mengemukakan bahwa anggaran sektor publik adalah susunan kegiatan yang di interpretasikan dalam bentuk perolehan pendapatan serta belanja yang dipresentasikan oleh satuan moneter.

Anggaran Sektor publik yang diungkapkan oleh Halim et al. [12] adalah suatu tools yang digunakan dalam mencapai tujuan, untuk melayani masyarakat agar dapat meningkatkan pelayanan serta kesejahteraan masyarakat. Dapat dikatakan bahwa anggaran sektor publik merupakan suatu alat yang digunakan untuk mengalokasikan segala sumber daya yang dimiliki dalam mencapai tujuan dan dituangkan dalam satuan moneter, hingga pada akhirnya tercipta kesehjahteraan masyarakat dan dapat memberikan penilaian terhadap kinerja pada periode tertentu.

\section{Electronic Budgeting (E-Budgeting)}

E-Budgeting adalah sistem penyusunan anggaran yang di dalamnya termasuk aplikasi program komputer berbasis web untuk memfasilitasi proses penyusunan anggaran belanja daerah. E-Budgeting bermula ketika
Pemerintah Kota Surabaya menyadari bahwa penyusunan anggaran yang lama, harga satuan item belanja tidak terstandar sehingga sangat mungkin terjadi penyelewengan, dan kenyataan bahwa Tim Anggaran Eksekutif kesulitan mengendalikan rapat dan tidak hapal rincian usulan dari Satuan Kerja Perangkat Daerah (SKPD), terlebih SKPD yang tidak menghadiri rapat. Maksud dan tujuannya adalah untuk memudahkan Tim Anggaran Eksekutif dalam penyusunan anggaran dan meningkatkan kualitas Anggaran Pendapatan dan Belanja Daerah (APBD) dari sisi kesesuaian dengan Rencana Pembangunan Jangka Menengah Daerah (RPJMD), keakuratan nilai dan rekening serta akuntabilitas alokasi belanja. Sistem ini memiliki manfaat sebagai berikut:

1. Proses yang transparan

2. Proses penyesuaian singkat dan tepat waktu

3. Anggaran sesuai dengan kebutuhan dalam kegiatan

4. Kronologis anggaran jelas

5. Report sesuai permintaan Ketua Tim Anggaran dapat terpenuhi.

Sistem e-Budgeting seperti program $e$ Government yang lain, memiliki keunggulan dalam efektivitas pekerjaan dan efisiensi biaya karena pekerjaan yang banyak dapat diselesaikan oleh sedikit orang dalam waktu yang cepat dan budaya paperless dalam $e$ Budgeting membuat pemerintah tidak perlu menyediakan banyak kertas bagi seluruh SKPD untuk mengisi formulir sehingga terjadi efisiensi biaya dalam pelaksanaannya.

E-Budgeting merupakan sistem informasi yang digunakan dalam proses penganggaran pemerintah. E-Budgeting digunakan dalam proses penganggaran sebagai sebuah sarana untuk mempermudah perolehan data standar satuan harga (terutama untuk komponen belanja langsung). Oleh karena itu, dibutuhkan pemahaman mengenai proses penyusunan APBD secara manual, sehingga dapat diketahui proses implementasi $e$-Budgeting dalam sebuah proses penyusunan APBD. Proses penyusunan APBD secara manual dapat membantu memberikan pemahaman, petunjuk teknis dalam penyusunan APBD, dan pemanfaatam dari sistem e-Budgeting yang dikembangkan oleh Pemerintah Provinsi DKI Jakarta dalam proses perencanaan dan penyusunan anggaran pemerintah daerah. Dengan mengetahui proses penyusunan APBD, dapat mengetahui pihakpihak yang terlibat dalam penyusunan APBD serta pihak-pihak yang menggunakan $e$ Budgeting dalam mproses penyusunan APBD. 


\section{Evaluasi Kebijakan Publik}

Evaluasi kebijakan publik biasanya dipahami sebagai evaluasi atas implementasi kebijakan saja [13]. Menurut [7], istilah evaluasi dapat disamakan dengan penaksiran (apparsial), pemberian angka (rating), dan penilaian (assessment). Evaluasi bersangkutan dengan hasil informasi mengenai nilai atau manfaat hasil kebijakan. Evaluasi memberikan informasi yang valid dan dapat dipercaya mengenai kinerja dari kebijakan, yaitu seberapa jauh kebutuhan nilai dan kesempatan telah dapat dicapai melalui tindakan publik. Evaluasi memberi sumbangan pada klarifikasi dan kritik terhadap nilai-nilai yang mendasari pemilihan tujuan dan target, serta memberi sumbangan pada metode-metode analisis kebijakan lainnya, termasuk rumusan masalah dan rekomendasi.

Menurut [14-15], evaluasi kebijakan publik memiliki empat fungsi, yaitu fungsi eksplanasi, fungsi kepatuhan, fungsi Audit, Fungsi Akuntansi. Keempat fungsi evaluasi tersebut berkenaan dengan ketepatan sasaran evaluasi terhadap kesesuaian pola dan penerapannya di lapangan, sehingga evaluator mampu memahami dan menyelesaikan permasalahan-permasalahan yang timbul.

\section{Model Evaluasi CIPP}

Model evaluasi ini banyak dikenal dan diterapkan oleh para evaluator. Konsep evaluasi model CIPP pertama kali diperkenalkan oleh Stufflebeam pada 1965 sebagai hasil usahanya dalam mengevaluasi ESEA (The Elementary and Secondar Education Act). Evaluasi model Stufflebeam terdiri dari empat dimensi, yaitu Context, Input, Process, dan Product, sehingga model evaluasinya diberi nama CIPP. Keempat dimensi tersebut merupakan sasaran evaluasi yaitu komponen dan proses sebuah program yang dilaksanakan. Jika dibandingkan dengan model penilaian lainnya, CIPP memiliki dimensi diantaranya konteks, input, proses, dan produk yang dapat menjadi alat penelitian, dengan tujuan untuk memfasilitasi serta lebih menekankan pada fokus yang akan dikembangkan, serta informasi yang didapatkan dapat membantu dalam pengambilan keputusan mengenai keberlanjutan suatu program dari segi perencanaan, penataan, serta berinovasi atau memodifikasi program yang sudah berjalan dengan lebih baik [10]. Keunggulan model evaluasi CIPP dibandingkan dengan model evaluasi lainnya adalah dengan menggunakan model CIPP, menghasilkan analisis mengenai kekuatan sertra kelemahan dari program yang dijalankan yang tujuannya untuk meningkatkan kualitas program tersebut [16]. Dalam penelitian Hakan et al. [17] dengan menggunakan model evaluasi CIPP dapat menilai sejauh mana program yang dijalankan berjalan secara efektif yang dilihat dari pencapaian tujuan, penggunaan sumber daya yang memadai baik sumber daya manusia dan infrasturktur teknologi informasi, serta output yang dihasilkan.

Merujuk pada penjelasan Darodjat [18] mengenai dimesnsi, dimensi pertama adalah evaluasi konteks. Konteks berfokus pada status dari objek secara keseluruhan, mengidentifikasi kekurangan, kekuatan, mendiagnosa masalah dan memberikan solusinya, menguji apakah tujuan dan prioritas disesuaikan dengan kebutuhan yang akan dilaksanakan. Dimensi kedua adalah evaluasi masukan untuk menentukan cara bagaimana tujuan program dicapai. Evaluasi masukan dapat membantu mengatur keputusan, menentukan sumbersumber yang ada, alternatif apa yang diambil, apa rencana dan startegi untuk mencapai tujuan, bagaimana prosedur kerja untuk mencapainya. Komponen dari evaluasi masukan ini adalah sumber daya manusia, sarana dan peralatan pendukung, serta berbagai prosedur dan aturan yang diperlukan. Dimensi ketiga adalah evaluasi proses, yaitu evaluasi yang digunakan untuk memprediksi rancangan prosedur atau rancangan implementasi selama tahap implementasi, menyediakan informasi untuk keputusan program, dan sebagai rekaman atau arsip prosedur yang telah terjadi. Evaluasi proses ini meliputi koleksi data penilaian yang telah ditentukan dan diterapkan dalam praktik pelaksanaan program. Dimensi terakhir, yaitu evaluasi produk, merupakan penilaian yang dilakukan untuk mengukur keberhasilan dalam pencapaian tujuan yang telah ditetapkan. Data yang dihasilkan akan sangat menentukan apakah program diteruskan, dimodifikasi atau dihentikan.

Berkenaan dengan evaluasi yang akan dilakukan serta berdasarkan uraian berbagai teori evaluasi tersebut, maka metode CIPP oleh Stufflebeam yang akan digunakan. Adapun berbagai pertimbangan yang menjadi dasar penentuan metode tersebut adalah: metode ini memiliki langkah-langkah yang jelas dan runtun dalam pengungkapan setiap urutan program; metode CIPP dapat menganalisa secara detail mulai dari proses perencanaan, aplikasi, implementasi dan kelanjutan; model CIPP ini merupakan model yang dikenal dan diterapkan para evaluator dibandingan dengan modelmodel lainnya. Berikut ini penjelasan empat komponen dari model evaluasi CIPP: 
1. Evaluasi Konteks (Context Evaluation)

Arikunto [19] menjelaskan bahwa evaluasi konteks menurut Stufflebeam digunakan untuk menjawab pertanya "apa yang perlu dilakukan?". Karenanya, evaluasi ini mengidentifikasi dan menilai kebutuhankebutuhan yang mendasari disusunnya program tersebut, misalnya seperti peraturan yang mendasari dibentuknya kebijakan, tujuan dari adanya kebijakan tersebut serta mengidentifikasi masalah-masalah yang berkaitan dengan kebijakan tersebut. Pendapat lain dikemukakan oleh Mahmudi [20] bahwa tujuan dari evaluasi konteks adalah mendiagnosis masalah-masalah yang dihadapi organisasi dan menilai apakah tujuan-tujuan dan prioritas-proioritas yang telah ditetapkan memenuhi kebutuhan-kebutuhan pihak-pihak yang menjadi sasaran organisasi.

2. Evaluasi Masukan (Input Evaluation)

Tahapan kedua yaitu evaluasi input, merupakan evaluasi yang digunakan untuk menjawab pertanyaan "bagaimana kita melaksanakanya?". Evaluasi ini mengidentifikasikan dan menilai aspek-aspek yang berperan dalam pengelolaan dan keberhasilan pelaksanaan program yang dijalankan. Hasil identifikasi tersebut dapat menjadi dasar dalam pengambilan keputusan mengenai langkah-langkah dan sumberdaya apa saja yang diperlukan untuk mencapai sasaran dan tujuan program [19]. Menurut Widyoko [21], evaluasi masukan membantu mengatur keputusan, menentukan sumber-sumber yang ada, alternatif apa yang diambil, apa rencana dan strategi untuk mencapai tujuan, dan bagaimana prosedur kerja untuk mencapainya. Komponen evaluasi masukan meliputi sumber daya manusia, sarana dan peralatan pendukung, serta berbagai prosedur dan aturan yang diperlukan.

3. Evaluasi Proses (Process Evaluasi)

Menurut Arikunto [19] evaluasi proses dalam model CIPP diarahkan pada seberapa jauh kegiatan dilaksanakan dalam program tersebut sudah terlaksana sesuai rencana. Evaluasi proses digunakan untuk mendeteksi rancangan prosedur atau rancangan implementasi serta menyediakan informasi untuk keputusan program dan sebagai rekaman prosedur yang telah tejadi.

\section{Evaluasi Hasil (Product Evaluation)}

Menurut Arikunto [19] tahapan terakhir dari model CIPP ini adalah evaluasi Produk (output), evaluasi ini bertujuan untuk menjawab “apakah program yang dilaksanakan berhasil?". Widyoko [21] berpendapat bahwa evaluasi hasil merupakan sebagai alat bantu dalam membuat keputusan selanjutnya, baik mengenai hasil yang telah dicapai maupun apa yang dilakukan setelah program itu berjalan. Evaluasi ini berupaya memberikan gambaran mengenai keluaran dan manfaat yang diperoleh dari pelaksanaan suatu program. Selain itu, hasil dari evaluasi proses diharapkan dapat membantu pimpinan dalam membuat keputusan yang berkenaan dengan kelanjutan dari implementasi suatu program apakah akan dilanjutkan, diakhiri maupun dimodifikasi.

\section{Metode Penelitian}

\section{Pendekatan Penelitian}

Penelitian ini berfokus pada pendeskripsian implementasi sistem e-Budgeting pada Pemerintah Provinsi Jakarta dengan alat analisis Model CIPP oleh Stufflebeam [8]. Penelitian ini menggunakan pendekatan kualitatif. Berdasarkan pendekatan yang digunakan maka peneliti menggunakan pendekatan studi kasus. Penelitian ini menggunakan pendekatan studi kasus sesuai dengan kriteria dari Yin [22] di atas, pertama, penelitian ini mengangkat fokus penelitian mengenai bagaimana implementasi sistem e-Budgeting pada Pemerintah Provinsi DKI Jakarta dengan alat analisis Model CIPP. Kedua, peneliti tidak memiliki peluang untuk mengubah atau mengandalkan implementasi sistem e-Budgeting secara langsung. Hal ini karena sistem e-Budgeting hanya digunakan oleh pihak-pihak yang berkepentingan. Ketiga, implementasi sistem $e$-Budgeting di Pemerintah Provinsi DKI Jakarta pada perencanannya tahun 2013 dan diterapkan pada tahun 2014, sehingga memenuhi kriteria fenomena kontemporer dalam pendekatan penelitian studi kasus.

\section{Metode Pengumpulan Data}

Data penelitian yang dikumpulkan dapat berupa keterangan tertulis, informasi lisan, dan beragam fakta yang berhubungan dengan masalah evaluasi implementasi. Sehubung dengan hal tersebut, maka dalam evaluasi ini digunakan dua teknik utama pengumpulan data, yaitu studi dokumentasi dan wawancara. Studi dokumentasi dalam pengumpulan data penelitian ini dimaksudkan sebagai cara mengumpulkan data dengan mempelajari dan mencatat bagian-bagian yang dianggap penting dari berbagai risalah resmi yang terdapat baik pada lokasi penelitian maupun pada instansi lain yang relevan dengan lokasi penelitian.

Peneliti melakukan wawancara secara mendalam (independent interview) sesuai 
dengan prosedur wawancara yang berkaitan dengan masalah yang diteliti serta menjelaskan aspek-aspeknya. Metode ini dilakukan dengan mewawancarai secara langsung dan mendalam kepada pihak-pihak yang terlibat, yaitu Tim Anggaran Pemerintah Daerah (TAPD) di antaranya Kepala Badan Pengelola Keuangan Daerah (BPKD), Developer dan Konsultan EBudgeting, Kepala Anggaran BPKD, Kepala Anggaran Sub Bidang Kesejahteraan Rakyat (Kesra), Kepala Anggaran Sub Bidang Pemerintah, Kepala Anggaran Sub Bidang Perekenomian, Staf Badan Perencanaan Pembangunan Daerah (Bappeda) Bidang Perencanaan, Pendanaan, dan Pembangunan (PPP), Tim Data Bappeda, Tim Data BPKD, Tim Penyelia Anggaran BPKD. Wawancara dilaksanakan oleh peneliti kepada informan sesuai dengan panduan pertanyaan yang telah dipersiapkan sebelumnya. Apabila data yang diperoleh dari beberapa informan terkait telah sama, data telah dianggap cukup.

\section{Analisis Data}

Pada penelitian ini, anlisis data dilakukan setelah data terkumpul,. Secara teknis, analisis data akan dilakukan dengan adaptasi teknik analisis data dalam penelitian kualitatif dari Miles dan Huberman [23]. Alasan peneliti menggunakan teknik analisis data dari Miles dan Huberman [23] karena rangkaian kegiatan dalam teknik analisis data dilakukan secara susul menyusul, berulang-ulang sampai akhirnya tercapai tujuan penelitian. Teknik analisis data penelitian kualitatif dari Miles dan Huberman [23] memiliki tiga langkah, yaitu sebagai berikut:

\section{Reduksi Data}

Tahapan ini meringkas data (hasil wawancara, observasi lapangan dan dokumentasi) yang diperoleh melalui wawancara dengan informan, kejadian, dan situasi pada lokasi penelitian. Kegiatan pertama dari tahapan reduksi data yaitu membuat transkip hasil wawancara dengan informan. Kegiatan kedua pada tahapan ini yaitu transkip hasil wawancara dibaca berulang-ulang dan apabila terdapat hal yang tiba-tiba muncul di pikiran ataupun yang muncul saat peneliti membaca data penelitian maka peneliti mencatat di kertas lain yang menunjukkan interpretasi sementara dari peneliti.

2. Penyajian Data

Penyajian data kualitatif dapat dilakukan dalam bentuk uraian singkat, bagan, hubungan antara kategori, flowchart, dan tabel, yang berfungsi untuk memudahkan dalam penjelasan dan penarikan kesimpulan. Pada tahapan penyajian data peneliti terlibat dalam kegiatan penyajian data yang telah dikumpulkan dan dilakukan analisis, penyajian data dilakukan dengan menyajikan informasi secara tematik kepada pembaca. Penyajian data bertujuan agar data hasil reduksi terorganisis, tersusun dalam pola hubungan sehingga semakin mudah untuk dipahami. Pada tahapan ini peneliti berusaha untuk menyajikan dan atau menyusun data secara relevan dengan menampilkan data hasil wawancara yang telah diyakini keabsahannya serta membuat hubungan dan memaknai atas fenomena yang terjadi sehingga dapat mengambil sebuah kesimpulan untuk menjawab tujuan dari penelitian.

3. Kesimpulan atau Verifikasi Data

Proses penarikan kesimpulan dan verifikasi adalah kesimpulan awal yang dikemukakan, bersifat sementara dan akan berubah bila tidak ditemukan bukti-bukti yang kuat dan mendukung tahapan pengumpulan data berikutnya. Kelengkapan dalam penelitian merupakan dasar dari verifikasi sebelum proses penarikan kesimpulan. Verifikasi data pada tahapan ini dilakukan dengan triangulasi data, yaitu membandingkan data wawancara dengan dokumen yang ada di lapangan, dan meninjau kembali hasil wawancara informan satu dengan informan lainnya. Setelahnya, dapat diambil kesimpulan yang lebih kuat dan dapat dipertanggungjawabkan.

\section{Hasil Penelitian dan Pembahasan}

\section{Penganggaran pada Pemerintah Provinsi DKI Jakarta}

Sebelum menggunakan e-Budgeting, sistem perencanaan penganggaran pada Pemerintah Provinsi DKI Jakarta pada dasarnya menggunakan dua sistem berbeda yang dimiliki oleh beberapa Satuan Kerja dengan wewenang dan tugas masing-masing. Dua sistem tersebut, yaitu Sistem Informasi Perencanaan (SIP) dan Sistem Informasi Pengelolaan Keuangan Daerah (SIPKD) yang bertransformasi menjadi sistem $e$-Budgeting. SIP menjadi tugas dan tanggung jawab Badan Perencanaan Pembangunan Daerah (Bappeda) sedangkan sistem SIPKD merupakan salah satu tugas dan tanggungjawab Badan Pengelola Keuangan Daerah (BPKD). 
Kedua sistem merupakan sistem yang saling berkaitan. SIP digunakan saat awal mula perencanaan penganggaran sedangkan sistem SIPKD digunakan untuk merinci perencanaan penganggaran tersebut.

SIP terdiri dari beberapa subsistem yang saling terintegrasi yang di antaranya adalah Sistem Infromasi Rencana Pembangunan Jangka Menengah Daerah (SI-RPJMD), Sistem Informasi Perencanaan (SIP) tahunan, Sistem Monitoring dan Evaluasi (SI-Monev) dan Sistem Informasi Musyawarah Perencanaan Pembangunan (SI-Musrenbang). SI-RPJMD digunakan untuk membuat input perencanaan pembangunan Provinsi DKI Jakarta selama 5 tahun atau selama masa kepemimpinan Gubernur terpilih. SI-RPJMD ini juga dibuat sinkron dengan rencana startegis (Renstra) masing-masing satuan kerja. SI-Musrenbnbg merupakan awal perencanaan kegiatan sebelum masuk ke SIP tahunan yang digunakan untuk menyerap aspirasi masyarakat secara langsung dan berjenjang dimulai dari tingkat Rukun Warga (RW). SIP tahunan digunakan untuk menginput perencanaan pembangunan Provinsi DKI Jakarta setiap tahunnya. SIP tahunan ini harus berdasarkan perencanaan pembangunan Jangka Menengah yang terdapat pada SIRPJMD dan rencana kerja Pemerintah Daerah (RKPD) pada tahun anggaran yang dituju SIP tahunan ini dimasukkan oleh masing-masing Satuan Kerja mulai dari tigkat kelurahan sampai dengan tingkat provinsi dengan Badan Perencanaan Pembangunan Daerah sebagai verifikator dan koordinatornya.

SI-Musrenbang dan SIP tahunan merupakan sarana masukan perencanaan pembangunan dengan metode yang berbeda di mana SI-Musrenbang menggunakan metode Bottom-Up yang digunakan untuk menjaring usulan perencanaan kegiatan dari warga masayarakat, sedangkan SIP menggunakan metode Top-Down dengan kegiatan yang diusulkan oleh pihak eksekutif. Namun SIMusrenbang tetap diinput ke dalam SIP tahunan dan dilakukan verifikasi oleh satuan kerja teknis terkait yang berada di bawah koordinasi Bappeda. SI-Monev digunakan untuk memonitor dan mengevaluasi pelaksanaan kegiatan tahunan berjalan berdasarkan apa yang telah ditetapkan oleh Pemerintah daerah dan Dewan Perwakilan Rakyat Daerah (DPRD) yang kemudian ditetapkan Peraturan Daerah. Secara sederhana, input proses perencanaan penganggaran dimulai dari SI-RPJMD, SIMusrenbang, SIP tahunan, Sistem SIPKD, dan terakhir kembali ke SI-Monev.
SIPKD mengalami evolusi besar-besaran dalam 2 tahun terakhir, Sistem Informasi tersebut digantikan dengan sistem e-Budgeting. Sistem e-Budgeting mulai diterapkan pada pertengahan 2013 dengan persiapan pembuatan hanya 1 semester, yaitu akhir semester tahun 2013. Sosialisasi sistem e-Budgeting dilakukan pada bulan November 2013 untuk 700 Satuan Kerja yang ada di Pemerintah Provinsi DKI Jakarta dan dilakukan bergiliran dalam rangka penyusunan APBD tahun Anggaran 2014.

\section{Hasil Evaluasi Implementasi e-Budgeting pada Pemerintah Provinsi DKI Jakarta}

1. Hasil evaluasi konteks menunjukkan bahwa implementasi e-Budgeting pada Pemerintah Provinsi DKI Jakarta telah mencapai sasaran, yaitu untuk mewujudkan efektivitas, efisiensi, akuntabilitas, dan transparansi pada proses perencanaan Anggaran Belanja Pemerintah Daerah (ABPD) serta memperbaiki sistem sebelumnya, yaitu Sistem Informasi Pengelolaan Keuangan Daerah (SIPKD). Pada tahap evaluasi konteks selain tujuan yang menjadi fokus utama yaitu kesesuaian antara implementasi $e$ Budgeting dengan kebijakan-kebijakan yang diterbitkan oleh pemerintah pusat dan daerah, hasil menunjukkan bahwa penerapan e-Budgeting sudah sesuai dengan Instruksi Presiden No. 3 tahun 2005 mengenai kebijakan dan strategi nasional pengembangan e-Government, Peraturan Pemerintah No.58 tahun 2005 dan Peraturan Menteri Dalam Negeri (Pemendagri) No. 13 tahun 2006 mengenai pengelolaan keuangan derah yang lebih maju, dan peraturan Gubernur Provinsi DKI Jakarta Nomor 145 tahun 2013 tentang penyusunan rancangan ABPD atau ABPD Perubahan melalui $e$-Budgeting. Di sisi lain, hasil dari evaluasi konteks menunjukkan perlu adanya berubahan paradigma pengguna sistem yang lama ke sistem yang baru, yaitu $e$-Budgeting.

2. Sedangkan dalam evaluasi input menunjukkan implementasi e-Budgeting pada Pemerintah Provinsi DKI Jakarta dilihat dari aspek infrastruktur teknologi informasi dan infrastruktur manusia dapat dikatakan sudah sesuai. Dari segi infrastruktur teknologi informasi pada pengadaan sarana dan prasarana yang digunakan baik Hardware dan Software sudah memadai, hanya saja diperlukan beberapa perbaikan terhadap server yang 
digunakan, karena pada waktu-waktu tertentu, apabila server sedang digunakan secara bersaman oleh TAPD, sering kali terjadi overload sehingga hal ini menjadi faktor kendala dalam implementasi $e$ Budgeting. Selanjutnya, hasil evaluasi input dari aspek infrastruktur manusia, Pemerintah Provinsi DKI telah melakukan pelatihan kepada pengguna e-Budgeting yaitu Bappeda, BPKD, serta kepada SKPD/UKPD. Pelatihan dan sosialisasi yang diberikan secara bertahap, melihat jumlah TAPD pada Pemprov DKI khususnya SKPD/UKPD begitu banyak. Hasil evaluasi input ini juga mengungkapkan bahwa Pemprov DKI selalu melakukan sosialisasi berkaitan dengan fitur-fitur atau inovasi-inovasi yang baru untuk menyempurnakan sistem e-Budgeting ini, inovasi yang dikembangkan tidak selalu berasal dari konsultan atau developer tetapi inovasi terkadang datang dari pengguna itu sendiri karena melihat kebutuhan di lapangan.

3. Hasil evaluasi proses menunjukkan secara teknis implementasi e-Budgeting pada Pemerintah Provinsi DKI Jakarta yang sudah berjalan sejak 2013 dan selalu mengalami perkembangan serta berinovasi sesuai kebijakan dan permasalahan yang muncul, sehingga pada akhirnya dapat memberikan manfaat hingga saat ini. Evaluasi proses mengungkapkan bahwa, penerapan e-Budgeting pada proses pengelolaan keuangan daerah memberikan dampak yang positif. Karena $e$-Budgeting dapat membantu dan mempermudah TAPD dalam menyusun Rencana Kegiatan dan Angaran (RKA) SKPD/UKPD serta meminimalisasi kesalahan-kesalahan yang mungkin terjadi dalam proses penyusunan APBD. Bagi BPKD dan Bappeda, $e$ Budgeting sangat membantu di antaranya dalam proses evaluasi perencanaan setiap SKPD/UKPD, menutup kemungkinan terjadinya anggaran yang tidak sesuai dengan perencanaan, dan keamanan data yang lebih terjaga. Pemerintah Provinsi DKI Jakarta selalu melakukan proses monitoring dan evaluasi terhadap sistem $e$ Budgeting, karena hal ini dirasa penting untuk perkembangan sistem ke depannya. Hasil evaluasi proses menunjukkan beberapa kendala yang perlu diperhatikan pada tahap implementasi, di antaranya penyesuaian terhadap aplikasi $e$ Budgeting, karena pada awalnya $e$ Budgeting ini digunakan oleh Kota
Surabaya yang memiliki kurang lebih 72 SKPD, lalu digunakan pada tingkat provinsi yang memiliki kurang lebih 740 SKPD/UKPD, sehingga dibutuhkan penyesuaian yang lebih. Hal lain yang perlu diperhatikan dari temuan evaluasi proses adalah penyiapan Standar Operasional Prosedur (SOP), pemerintah DKI Jakarta dalam implementasi $e$ Budgeting pada penerapannya masih menggunakan Peraturan Gubernur (Pergub) No. 145 mengeni pembagian tugas dan wewenang, untuk SOP yang diberlakukan secara legal masih pada tahap penyusunan.

4. Hasil evaluasi produk atau output mengungkapkan bahwa dengan implementasi e-Budgeting pada Pemerintah Provinsi DKI Jakarta, sistem ini membantu pada proses penyusunan RKA yang nilai dan komponen di dalamnya dapat dipertanggungjawabkan. Hasil evaluasi produk lainnya menunjukkan dengan menggunakan $e$ Budgeting proses penyusunan anggaran lebih lebih singkat dan tepat waktu, meningkatkan kinerja aparatur pemerintah dalam hal penyiapan anggaran belanja daerah, meningkatkan transparansi, akuntabilitas, efektivitas, dan efisiensi anggaran. Selain itu, dengan menggunakan e-Budgeting meningkatkan kualitas ABPD dari sisi kesesuaian dengan dokumen perencanaan RPJMD (Rencana Pembangunan Jangka Menengah Daerah). Pengungkapan hasil evaluasi output dapat dilihat dari dua sisi, yaitu efektivitas dan efisiensi. Sisi efektivitas yang dicapai dari e-Budgeting adalah adanya kesesuaian RKA dengan RPJMD yang ditetapkan karena didalamnya memuat secara rinci alokasi belanja dari kegiatan dan penggunaan standar harga, dengan penggunaan standar harga satuan diharapkan tidak ada lagi perbedaan penggunaan harga komponen antar wilayah. Sedangkan dari sisi efisiensi terlihat dari ketepatan waktu dalam penyusunan RKA, pembagian tugas dan wewenang yang jauh lebih jelas, serta adanya manajemen kendali anggaran yang berperan aktif.

\section{Kesimpulan}

Dapat ditarik kesimpulan bahwa implementasi e-Budgeting pada Pemerintah Provinsi DKI Jakarta layak untuk dilanjutkan karena terbukti 
berjalan secara efektif bila dilihat dari prespektif model CIPP. Ditinjau dari konteks (context) yang berfokus terhadap keberhasilan dari pencapaian tujuan awal, telah tercipta transparansi dan akuntabilitas anggaran pada Pemerintah Provinsi DKI Jakarta. Pada komponen yang kedua, yaitu masukan (input), mengungkapkan bahwa penggunaan infrasturktur teknologi informasi berupa sarana dan prasarana yang ada sudah baik dan memadai akan tetapi masih memiliki kelemahan terhadap server yang digunakan. Selanjutnya, penggunaan sumber daya manusia atau infrastruktur manusia sudah memadai karena pada tahap implementasinya Pemerintah Provinsi DKI Jakarta selalu memberikan pelatihan serta sosialisasi terhadap seluruh TAPD.

Berdasarkan komponen ketiga dari model CIPP, yaitu Proses (process), hasil dari evaluasi dari tahap ini menyebutkan bahwa dengan menggunakan aplikasi atau sistem $e$-Budgeting, TAPD lebih mudah dan membantu dalam proses penyusunan RKA serta dampak positif yang diungkapkan dari hasil evaluasi proses ini yaitu lebih meminimalisisr kesalahan-kesalahan dalam penginputan serta proses penyusunan RKA. Selanjutnya, mengenai pembagian tugas dan wewenang yang lebih jelas, hal yang masih perlu diperhatikan pada tahap implementasi $e$ Budgeting adalah adanya SOP yang harus segera disusun. Ditinjau dari komponen yang terakhir, yaitu hasil (product), hasil evaluasi ini menyebutkan dengan adanya implementasi $e$ Budgeting pada Pemerintah Provinsi DKI Jakarta lebih meningkatkan kualitas APBD dari segi kesesuaian dengan dokumen perencanaan RPJMD (Rencana Pembangunan Jangka Menengah Daerah). Selain itu, hasil dari adanya e-Budgeting adalah manajemen kendali anggaran yang berperan aktif.

\section{Implikasi Penelitian}

Penelitian ini memberikan beberapa implikasi, yaitu dari sisi teoritis memberikan penjelasan bahwa penggunaan moderl CIPP sebagai alat analisis dapat membantu memberi gambaran mengenai suatu implementasi suatu program khususnya pada kebijakan publik, termasuk dalam kebijakan implementasi penggunaan teknologi informasi dalam mengelola kegiatan pemerintah untuk mencerminkan prinsip good governance, yaitu transparansi dan akuntabilitas dengan penerapan e-Government yang salah satu fungsinya yaitu untuk mengelola keuangan pemerintah daerah dengan menggunakan sistem e-Budgeting. Penelitian ini menunjukkan bahwa dengan menganalisis dengan menggunakan CIPP dapat mengidentifikasi dari berbagai sudut yaitu dari konteks, masukan, proses, dan yang terakhir adalah hasil atau output yang diberikan dari kebijakan tersebut.

Dari sisi praktis, penelitian ini memberikan sumbangan pemikiran bagi seluruh aparatur pemerintah untuk lingkup Pemerintah Provinsi DKI Jakarta serta pemerintah daerah lainnya yang akan menerapkan sistem e-Budgeting, sehingga para aparatur memahami proses pengembangan aplikasi e-Budgeting. Pengembangan tersebut dibagi dalam beberapa tahapan, yaitu tahap perencanaan untuk menganalisis tujuan dari sistem yang akan dibuat dan disesuaikan dengan tujuan organisasi, serta kesesuaian dengan peraturan atau kebijakan-kebijakan yang mendukung. Selanjutnya, tahap analisis, yaitu untuk memperbaiki sistem yang telah ada sehingga dapat memberikan gagasan untuk perbaikan sistem dan tahapan yang terakhir, yaitu implementasi sistem yang harus diperhatikan antara lain, pelatihan, penyiapan sarana, dan prasarana pendukung sistem yang akan digunakan. Tahapan ini berfokus pada persiapan yang dilakukan dalam menjalankan sistem tersebut.

Dari sisi kebijakan, hasil penelitian ini diharapkan dapat memberikan masukan kepada Pemerintah Kota Jakarta mengenai implementasi program e-Budgeting, sehingga dapat menjadi acuan dalam melakukan penyempurnaan terkait kebijakan penggunaan sistem informasi dalam mengelola keuangan Pemerintah guna mewujudkan good governace dari segi akuntabilitas, transparansi, efektifitas, dan efisiensi.

\section{Keterbatasan Penelitian}

Keterbatasan penelitian ini adalah kurang luasnya informan yang digunakan. Untuk meningkatkan efektivitas dari waktu pelaksanaan penelitian, peneliti lebih berfokus pada faktor internal BPKD dan Bappeda Provinsi DKI Jakarta. Seharusnya penelitian ini juga menambahkan informan dari DPRD. Penambahan informan dari pihak DPRD akan memperkaya informasi mengenai implementasi e-Budgeting dalam proses perencanaan dan penganggaran daerah.

\section{Saran}


Berdasarkan kesimpulan dan implikasi yang telah diuraikan, dengan segala keterbatasan, penulis mencoba untuk memberikan beberapa saran, yaitu:

1. Perlu adanya peningkatan kapasitas dari jaringan serta server agar kegiatan operasional pada tanggal-tanggal tertentu saat seluruh SKPD/UKPD melakukan proses input tidak terjadi overlaod.

2. Pemerintah Provinsi DKI Jakarta memerlukan SOP secara legal, sehingga implementasi e-Budgeting pada Pemerintah Provinsi DKI Jakarta dalam mengelola kegiatan pemerintah khususnya pengelolaan keuangan daerah menjadi lebih sempurna.

3. Diharapkan, selalu ada pengembangan atau terobosan yang lebih lagi dari yang sekarang, mengikuti perkembangan masalah yang ada. Salah satunya yaitu memasukan monitoring kedalam sistem $e$ Budgeting, sehingga dapat melihat realisasi kegiatan-kegiatan yang dilakukan oleh SKPD/UKPD.

4. Penelitian selanjutnya dapat melakukan penelitian kebijakan terbaru yang diimplementasikan oleh Pemerintah Provinsi DKI Jakarta yaitu Cash Less.

\section{Referensi}

[1] Undang - Undang Republik Indonesia Nomor 14 Tahun 2008 tentang Keterbukaan Informasi Publik.

[2] Sari, Kusuma Dewi Arum, Wahyu Agus Winarno. (2012). Implementasi EGovernment System dalam Upaya Peningkatan Clean and Good Governance di Indonesia. JEAM. Vol. 11 No.1

[3] Instruksi Presiden Republik Indonesia Nomor 3 Tahun 2003 tentang Kebijakan dan Strategi Nasional Pengembangan eGovernment

[4] United Nations E-Government Survey. (2016). E-governemnet in Support of Sustainable Development. Departement of Economic and Sosial Affairs.

[5] Kementerian Koordinator Bidang Perekonomian - Republik Indonesia. (2015). Tinjauan Ekonomi dan Keuangan (Mendorong Pembangunan Infrastruktur Demi Pemerataan Kesejahteraan Masyarakat). Vol. V. No. 4: April 2015

[6] Davis, F,D, Bagozzi, R.P., Warshaw, P,R. (1989). User Acceptance of Information Technology: A Comparison of Two
Theoritical Model. Management Science, 35. 982-1002.

[7] Weber, Ron. (1999). Information System Control and Audit. Prentice Hall Inc. Illinois USA

[8] Stufflebeam, Daniel L. (2003). The CIPP Model For Evaluation. International handbook of Educational Evaluation. Dorderecht: Kluwer Academic Publishers

[9] Yahaya. Azizi Hj. (2001). The Using Of Model Context, Input, Process and Products (CIPP) Learning Programs Assessment. Fakulti Pendidikan. Universiti Teknologi Malaysia: Sudai, Johor.

[10] Hasan, A ., Yasin, S.N.T.M., Yunus, M.F.M. 2015. A Conceptual Framework For Mechatronics Curriculum Using Stufflebeam CIPP Evaluation Model. Procedia Social and Behavioral Science 195 (2015) 844-849. DOI: 10.1016/j.sbspro.2015.06.324

[11] Mardiasmo. (2009). Akuntansi Sektor Publik. Yogyakarta: Andi

[12] Halim, Abdul, Muhammad Syam kusufi. (2014). Teori, Konsep, dan Aplikasi Akuntansi Sektor Publik dari Anggaran Hingga Laporan Keuangan Dari Pemerintah Hingga Tempat Ibadah. Jakarta: Salemba Empat

[13] Dwidjowijoto, R.N. (2004). Kebijakan Publik Formulasi, Implementasi dan evaluasi. Jakarta: PT. Elex Media Komputindo Kelompok Gramedia.

[14] Nugroho, R. (2006). Kebijakan Publik untuk Negara-negara Berkembang. Jakarta: PT. Elex Media Kompetindo.

[15] Nordiawan, Deddi. (2006). Akuntansi Sektor Publik. Jakarta: Salemba Empat

[16] Mohebbi, N., Akhlaghi, F., Yarmohammadian, M.H., Khoshgam, M., 2011. Application of CIPP model For Evaluating the Medical Records Education Course at Master of science level at Iranian Medical Science Universities. Procedia Social and Behavioral Science 15 (2011) 3286-3290. DOI: 10.1016/j.sbspro.2011.04.287

[17] Hakan, K., Seval, F. (2011). CIPP evaluation Model Scales: Development, Reliability, and validity. Procedia Social and Behavioral Science 15 (2011) 592599. DOI: $10.1016 /$ j.sbspro.2011.03.146

[18] Darodjat, Wahyudhiana.M. (2015). Model Evaluasi Program Pendidikan. ISLAMADINA. Vol XIIV. No. 1

[19] Arikunto, Suharsimi. 2014. Penelitian Tindakan Kelas. PT. Bumi Aksara: Jakarta 
[20] Mahmudi, Ihwan. (2011). CIPP: Suatu Model Evaluasi Program Pendidikan. Jurnal At-Ta'dib. Vol.6.No.1

[21] Sesmiarni, Zulfani. (2014). Model Evaluasi Program Pembelajaran. Bandar Lampung: Aura Printing \& Publishing.

[22] Yin, R, K.(2014). Case Study Research: Design and Methods. Mudzakir, M Djauzi (penerjemah). Studi Kasus: Desain \& Metode. PT Raja Grafindo Persada. Jakarta.

[23] Miles, M.B., and Huberman, A.M. (2009). Analisis Data Kualitatif. Universitas Indonesia Press. Jakarta. 